\section{UC program helps small farmers reap big harvest}

\author{
John Stumbos
}

I $\mathrm{n}$ the Sierra Nevada foothills, new farmers learn to use cover crops and biological pest controls to protect the organic produce they grow for farmers' markets, upscale restaurants and grocery stores.

In the San Joaquin Valley, refugees from Cambodia, Laos, Thailand and Vietnam learn new ways to grow and sell their native specialty vegetables and herbs in a world far from their birthplaces.

In northwestern California's remote Trinity Alps, residents bolster the local economy's traditional timber base by collecting, growing and marketing mountain herbs and wild forest products.

The common thread among these three groups is the University of California's Small Farm Program, which targets smallscale farmers and ranchers whose research and education needs are not addressed directly by other UC programs. In each example cited - and in many others like them - the program plays catalyst, counselor, researcher and educator in the struggle for survival and success.

The program began modestly in 1979 when the state Legislature earmarked funds for two farm advisors to work exclusively with "limited resource" Hispanic farmers. It now consists of a Small Farm Center at UC Davis, five small farm advisors, and an academic core of about 30 other farm advisors and more than a dozen Cooperative Extension specialists and campus faculty. This network provides support for California's rapidly growing population of subsistence, ethnic, entry-level, small-acreage and part-time farmers.

Left, the state's primary source of sugar peas is the Central Coast, which encompasses 4,500 acres of this specialty crop. Farm Advisor Louie Valenzuela (not pictured) has developed numerous sugar pea cultural techniques.
Nonfarmers also benefit from this flourishing segment of California agriculture. For example, certified farmers' markets have blossomed from a handful 10 years ago to nearly 200 today. Urban dwellers can now buy fresh, locally grown produce and talk directly to farmers. Specialty crop farmers have enriched the culinary palettes of gourmet chefs with arugula and red mustard; cinnamon basil and fennel; edible flowers like borage and nasturtium; mild Poblano chile peppers or fiery hot jalepeños; plumcots, kumquats and other rare fruits; sweet corn and sweet onions; chanterelle and shiitake mushrooms; and succulent heirloom tomatoes. Southeast Asian farmers are acquainting other Americans with long beans, mokwa, daikon and lemongrass. Small-scale organic farmers, persistent in dispelling the mystery of sustainable agriculture, have successfully encouraged the academic community to explore more environmentally sensitive farming practices.

Small farmers contribute more than $\$ 1$ billion in annual farm sales. They purchase one-third of the state's farm machinery and they pay more than one-third of agriculture's property taxes. And although farms continue to disappear from much of rural America, they are actually increasing in California. (See p. 6.) Much of that growth is among farms and ranches served by the UC Small Farm Program.

The success of any university public service program is incremental and usually can only be fully appreciated in retrospect. In discussions with farmers themselves, however, it is obvious that the UC Small Farm Program has made a big difference, an impression reinforced by a recent review of the program by a team of Cooperative Extension advisors, specialists and managers. They concluded that the program is "integral to the long-term

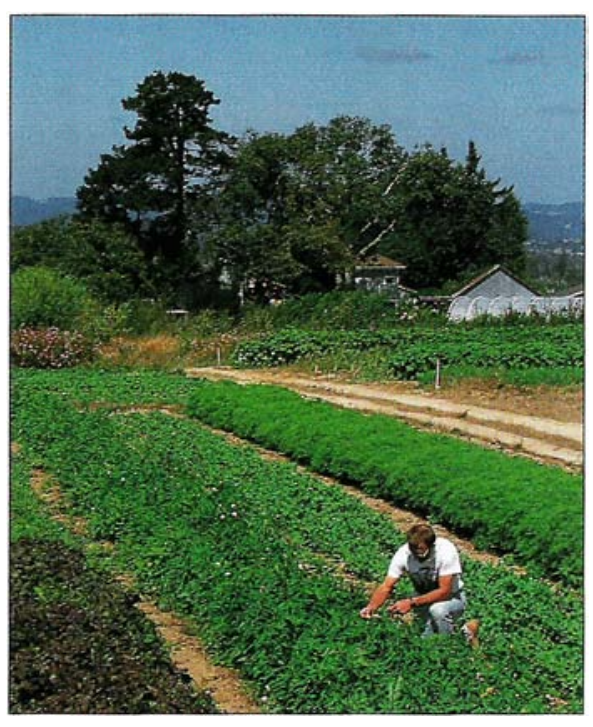

Stan Devoto grows diversified crops - including cut flowers and 50 varieties of apples - on his 20-acre Sonoma County farm.

success of California's many and varied small farmers."

\section{A brief history}

The Small Farm Program's origins can be traced to the early 1970s, when increasingly sophisticated production practices were enabling farmers to manage larger acreages. Easily obtained credit and falling commodity prices also accelerated consolidation. Simultaneously, there was growing public concern for farm workers and minorities in agriculture, and for the future of the family farm.

In 1972, Cooperative Extension secured a grant for five bilingual interns to build rapport with Latinos in Yolo, San Benito, Sacramento, Ventura and Riverside counties. In 1973, federal Rural Development Act funds were designated for two staff research associates, Pedro Ilic in Fresno County and Alfonso Durazo in Imperial County, to work with small-scale Hispanic producer cooperatives. Momentum for a university program continued to build in the 1970 s as regional conferences and workshops identified the obstacles facing small-scale farmers.

An important milestone in the program's development was a 1977 study of the family farm. More than 80 persons from colleges and universities, financial institutions, government agencies and affiliated agricultural organizations formed the Small Farm Viability Project. In six task forces, they analyzed marketing, finance, training, technology, natural resources and community services to identify the keys to the family farm's continued survival. Their report, The Family Farm in California, recommended a larger role for the university: UC research could boost family farm productivity and profitability; its Extension farm advisors could foster sound continued on p. 7 
specialty fruits and vegetables.

Ron Voss, director of UC's Small Farm Program, concludes that small farmers have had a lasting influence on California agriculture, particularly in the organic farming movement, which has brought issues of sustainability, environmental quality and food safety to the attention of the academic community - and of the public. Today's nearly 200 certified farmers' markets are populated mostly by small farmers. Representing diverse cultures, small farmers bring new customs, cuisines and traditions to their communities. Nearly all farms run by women and ethnic minority farmers are small.

"Small farmers," Voss says, "are helping to educate a population of Californians several generations removed from the farm about the origin and nature of their food. Small farms also are major contributors to the preservation of California's rapidly vanishing open space both near and far from urban centers."

For many years, U.S. census data have shown farm numbers declining and average farm size increasing. For instance, of the 6 million farms in the United States in 1940, 133,000 were in California. By 1978 the number of farms had dropped to 2.2 million nationally and to 73,000 in California. Average farm size grew to 450 acres statewide and nationally.

Within the last decade, however, the size of the average California farm has dropped to 360 acres, but farm numbers have increased to 81,000 . Nationally, farm
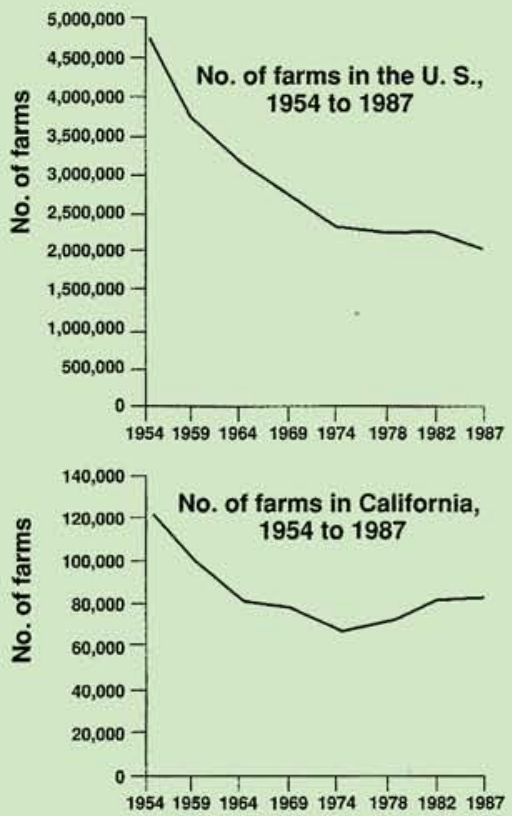

Fig. 4 The total number of farms in the U.S. has been declining since at least 1954. California followed the same trend until 1974, but since then the total number of farms in California has been increasing.

\section{Economic Impact:}

Small farms in California*...

Have total sales of over $\$ 1$ billion per year.

Own $31 \%$ ( $\$ 1.3$ billion worth) of the market value of the machinery and equipment used on farms.

Own $57 \%(90,551)$ of the trucks and pickups used on farms.

Own $53 \%(80,498)$ of the wheel tractors used on farms.

Pay 38\% (\$93 million) of the property taxes paid by farms in the state.

Receive $15 \%$ ( $\$ 36.7$ million) of government payments to farms.

\section{Characteristics:}

Small farms in California...

Represent $79 \%$ of the farms in the state.

Represent $36 \%$ of the land in farms.

Average 167 acres in size.

Are more than twice as likely to be owned by an individual or family than are large farms ( $84 \%$ vs. $40 \%$ ).

Represent $91 \%$ of farms operated by women.

Represent $83 \%$ of farms operated by people of Spanish origin.

Represent $73 \%$ of farms operated by people of black and other non-white races.

"Small farms are those with sales between $\$ 1,000$ and $\$ 99,999$. Data based on the 1987 Census of Agriculture for California, table 52.

size has edged up to 467 acres. To a large extent, the trend in California can be explained by the increase in farms in the $\$ 10,000$-to- $\$ 100,000$ category (an increase of $22 \%$ from 1982 to 1992 ).

Income and acreage figures help identify small farmers, but the Small Farm Program asks other questions in developing educational programs: Is a family operating the farm? Is the family gaining its livelihood from farming? What kind of education is needed? What kinds of experience do small farmers offer? What kinds do they lack? What are the cultural and language barriers? Answers to these questions indicate that California's small farmers encompass a broad spectrum of ethnicity, age, employment status, philosophical orientation, production methods, marketing goals, growing conditions, and crop or animal mix.

In the 1970s, the program's primary audience was Hispanic farm workers trying to establish independent farms. Today, the audience includes Southeast Asian refugees, organic farmers, specialty crop and animal growers, farmers' market managers, retirees, part-timers and others. "Their specific needs may vary," Voss says, "but what they have in common is a need for information that will help them succeed. The Small Farm Program's purpose is to help them toward that end." - J. Stumbos

Sources: 1978,1982 and 1987 data from the Census of Agriculture, 1987, U.S. Department of Commerce, Bureau of the Census. 1992 data from Farm Numbers/Land in Farms, USDA National Agricultural Statistics Service.

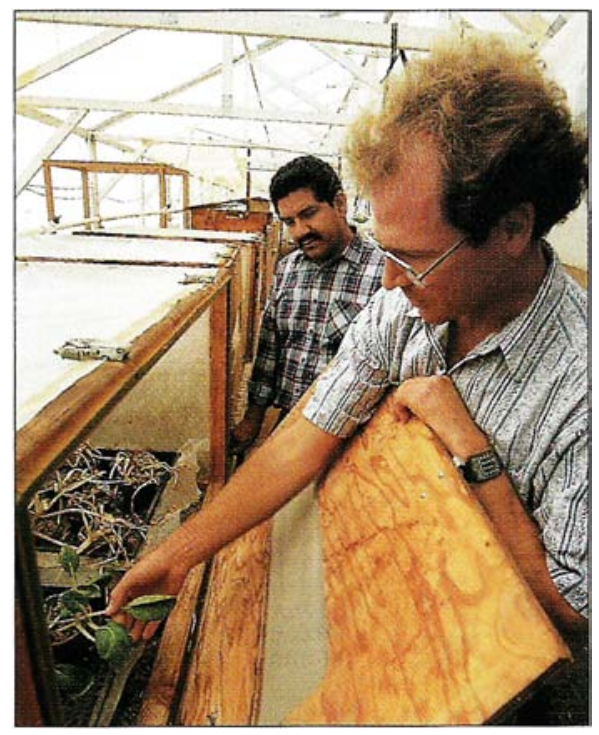

Jim Davis, president of Escondido's American Insectaries, inspects beneficial insects as Farm Advisor Faustino Muñoz looks on.

\section{UC program (continued from p. 5)}

practices and solve technical problems for specific crops.

Some individuals involved in the project formed the Small Farmer Information Access Council, which in 1979 recommended creation of what would eventually become the Small Farm Center at UC Davis. The center has built upon the early success with Hispanic growers to establish strong links between the university and today's more diverse small farm community.

Ilic and Durazo became the first "limited resource" farm advisors in 1979, when the Legislature appropriated funds specifically for university assistance to Hispanic growers. Durazo left the university in 1986; Hic continues in Fresno County as one of five Cooperative Extension farm advisors who work exclusively with small-scale, limited-resource farmers. The other four are Richard Smith, headquartered in San Benito County; Manuel Jiménez, headquartered in Tulare County; Louie Valenzuela, headquartered in Santa Barbara County; and Faustino Muñoz, headquartered in San Diego County.

\section{A specialized niche}

"Defining a small farm is difficult without being too specific or too general," says the program's director, Ron Voss, a Cooperative Extension vegetable specialist. "They range from ranches of several hundred acres to backyards in the cities."

Within those extremes is a dynamic clientele with a diverse range of informational needs beyond the scope of traditional Extension programs. Each year the Small Farm Program receives thousands of inquiries about specialty crops and livestock, direct marketing, organic growing, ethnic and minority farming and entry- 


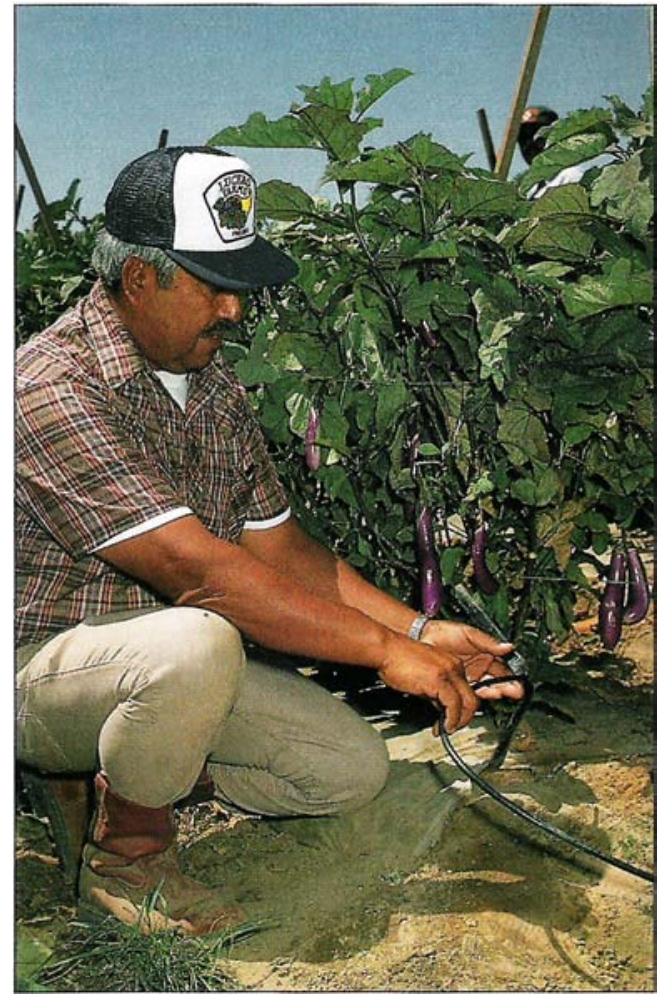

level farming. While the program does not exclude anyone seeking information about small farming, it does target its seminars, workshops, field days and other forms of public outreach at those who are serious about tapping into this important agricultural niche.

As a general guideline, the program focuses on farms grossing between $\$ 10,000$ and $\$ 100,000$, although those grossing less than $\$ 10,000$ are not excluded. In fact, Voss says, many of today's successful small farmers started out in this "mini-farm" or "hobby farm" category, which today comprises about one-third of California's 80,000 farms.

Economically, the odds can appear stacked against small farms. Credit can be difficult to obtain from lenders and the economies of scale seem to favor large operations.

"Small farmers who attempt to compete with large farmers in production of the high-volume commodities (such as lettuce), and who attempt to utilize the same marketing channels, struggle economically," Voss notes. "Large farms compensate for low profit margins with high volume; small farms cannot."

However, he adds, other factors have enabled small farms to carve out an economically sustainable niche for themselves. For instance, successful small-scale producers diversify their crop mix and utilize alternative marketing channels, such as farmers' markets and roadside stands, that allow them to keep a higher percentage of the consumer dollar.

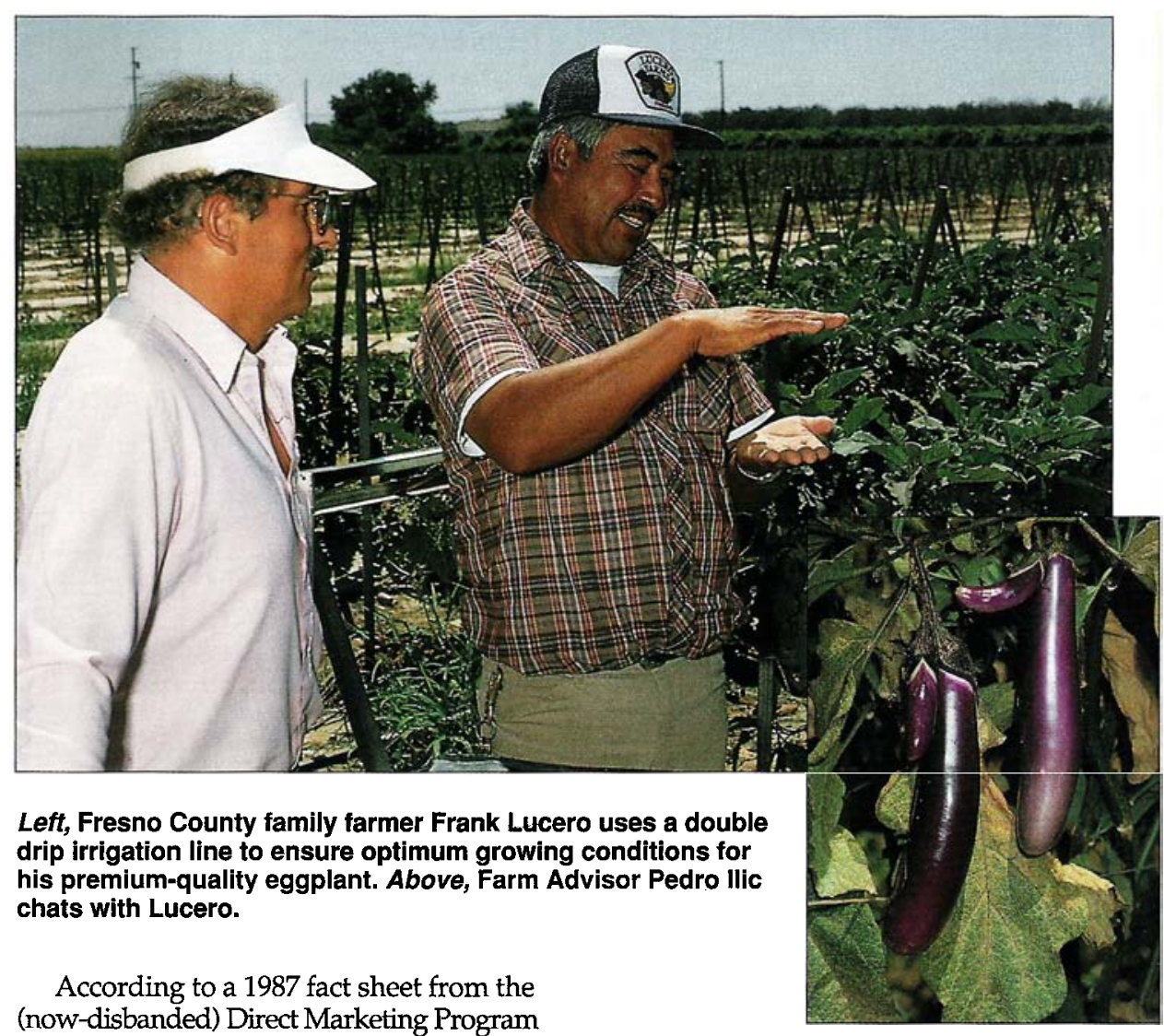

of the California Department of Food and Agriculture, for each dollar spent on agricultural products, farmers receive approximately 30 cents through conventional marketing channels and 56 cents through direct marketing. In other words, farmers may earn up to $80 \%$ more on goods sold directly to consumers - whether through farmers' markets, roadside stands, "u-pick" operations or mail order.

While high-volume commodities such as lettuce, rice and beef compel their growers to emphasize production efficiency, many of the agricultural products grown by small-scale farmers offer a comparatively higher rate of return. Specialty fruits and vegetables grown for upscale restaurants are a good example. So, too, are the increasing number of Oriental herbs and vegetables now produced for California's growing population of Southeast Asian immigrants.

Nonetheless, farming is a difficult way to make a living and many small-scale farmers must rely on additional sources of income to make ends meet. Statistics from the 1987 Census of Agriculture, the most recently available data, showed that a significant percentage, $42 \%$, of those grossing between $\$ 10,000$ and $\$ 100,000$ from their farms listed other jobs as their principal occupation. As UC Davis Extension Economist Desmond Jolly points out, the decision to operate a small farm may be motivated more by a desire for a rural lifestyle than any intent to earn all their economic livelihood from farming.

Jolly does not believe, as some economists and policymakers do, that small farms are somehow "wasteful enterprises that represent an irrational allocation of resources." (See p. 19) On the contrary, he says, small farms make important contributions to agricultural production by virtue of their willingness to grow new crops and to develop innovative new practices.

\section{Pedro llic}

Ilic has seen his clientele change (see sidebar, p. 9). At first, his primary job was to help 300 small-scale Hispanic vegetable growers gain access to Cooperative Extension's resources. Although university research and extension are available to all Californians, Spanish-speaking farmers needed help in overcoming language and cultural barriers.

Many farmers had been organized into producer cooperatives by the U.S. Department of Agriculture. "The idea of rural economic development at that time was to get people on the land and teach them to be farmers," Ilic recalls. The cooperatives did not prove economically viable, however, and eventually disintegrated. Sadly, several of Ilic's original clients no longer farm.

"These farmers were forced out of business because they could not get operating continued on $p .10$ 

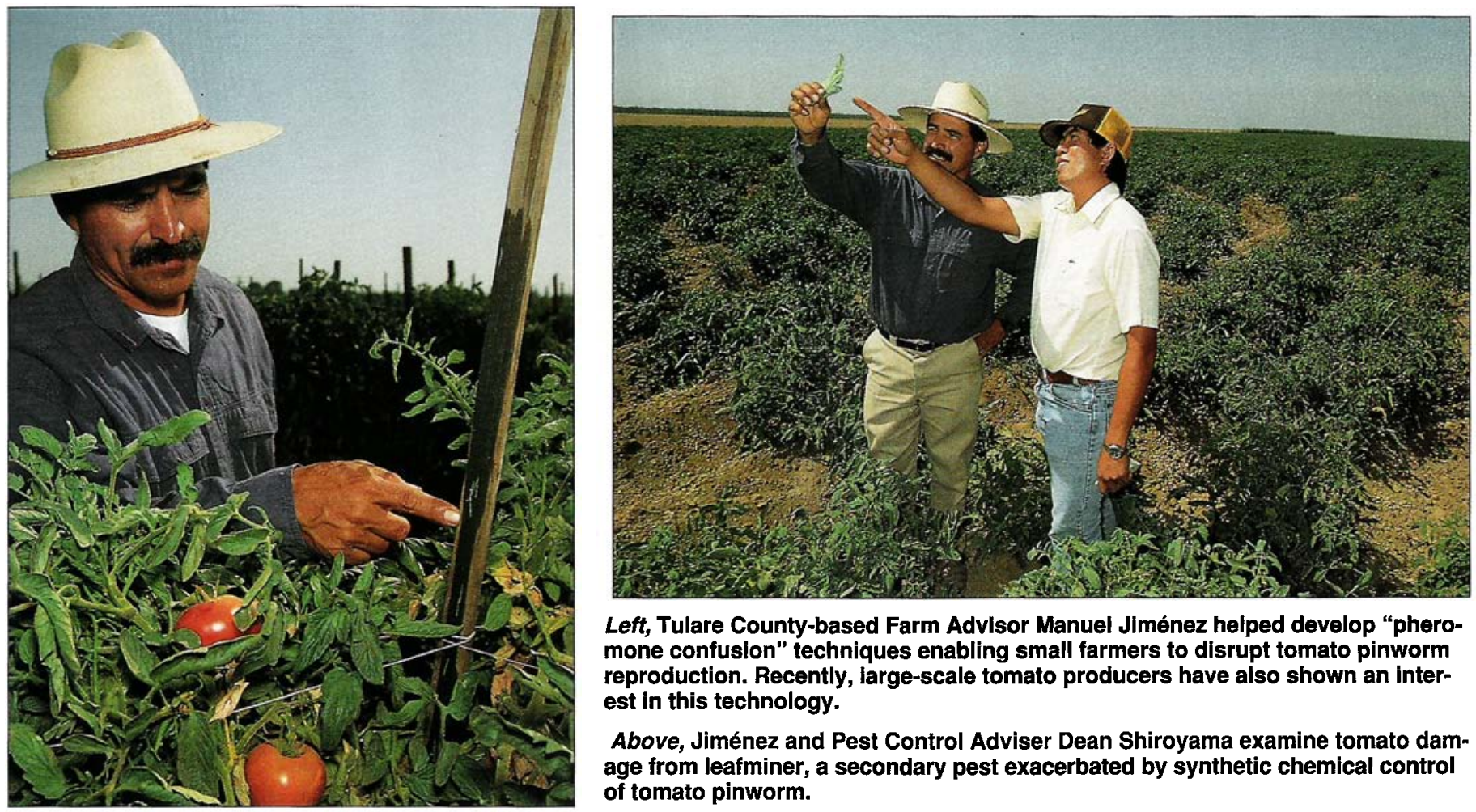

Left, Tulare County-based Farm Advisor Manuel Jiménez helped develop "pheromone confusion" techniques enabling small farmers to disrupt tomato pinworm reproduction. Recently, large-scale tomato producers have also shown an interest in this technology.

Above, Jiménez and Pest Control Adviser Dean Shiroyama examine tomato damage from leafminer, a secondary pest exacerbated by synthetic chemical control of tomato pinworm.

\section{UC program (continued from $p .8$ )}

loans, could not get a good handle on the market, were taken advantage of by brokers, didn't have the support of the UC system or didn't make the right decisions concerning what crops to grow and with whom to market," Ilic says. "Also, at that time there were no farmers' markets, which limited their marketing options significantly."

Among the small-scale Hispanic vegetable growers who beat the odds are Frank Lucero and his sons, Ken and Gary. Lucero purchased his farm in the early 1970s and expanded slowly to today's 75 acres of grapes and 20 acres of eggplant, chile peppers, watermelon and squash. As a true family unit, the

Luceros share jobs all year. Youngest son Ken early on explored the technological innovations Ilic was promoting - plastic tunnels for early season vegetable growth, fumigation with plastic mulches and drip irrigation.

The Luceros continue to improve quality, save labor and enhance efficiency. For instance, they have created innovative farm machinery for their eggplants that shapes a planting bed while simultaneously laying down drip-irrigation line, plastic mulch and hoops for an early season tunnel. The double drip line delivers precisely measured amounts of water and fertilizer for optimal growth.

One reason the Luceros are successful: they emphasize quality. Misshapen and substandard eggplants are culled. Harvested "eggs" are cooled down instantly in a water bath and sent immediately to cold storage.
"We know what we pack and we get a premium for it," the elder Lucero says.

Content to farm on a small scale, the Luceros saw what happened to neighbors who grew too fast and could not generate enough income from a faltering vegetable market to pay the bills. "You can be happy with a small farm," Ken says, "just as long as you work hard and don't spend your money foolishly."

Ilic adds, "These are the farmers our UC economists predicted would never succeed. It's a myth that small farmers are a dying breed."

\section{Faustino Muñoz}

Southernmost of the designated small farm advisors is Faustino Muñoz in San Diego County, where agriculture has dramatically shifted to high-value specialty crops because of the high cost of water and land (see opposite page).

Historically, the area's limited-resource farmers grew conventional vegetable crops: pole tomatoes, bell peppers, cucumbers and squash. Subsequently, intense competition from producers in Baja California drove many out of business or forced others to switch to baby squash, zucchini flowers and French beans.

Brothers Joe and Carlos Rodriguez, seeing the need to carve out a specialized niche on their 100-acre farm near Escondido, attended one of Muñoz's first organic farming seminars. Gradually, they weaned themselves from using conventional agrichemicals, and now these third-generation farmers have success- fully made the transition to "certified" organic methods.

To meet the requirements of California Certified Organic Farmers, growers must use nonsynthetic sources of fertilizer, such as composted chicken manure and legume cover crops, to get nitrogen to their vegetables. Pest control is similarly restricted. To control aphids, thrips, leafminers and assorted beetles, they now rely on Bacillus thuringensis, a bacterium that gives insects a lethal dose of disease, or on parasitic wasps, like Diaeretiella rapae, that attack cabbage aphids by laying their eggs inside the pest.

"We noticed that when we started using fewer pesticides, we had better control of pests by bringing in beneficial insects," Joe Rodriguez says. "Before, we would use Category 1 chemicals and lose control over insects - but using chemicals that aren't as strong is better because the insects don't build up a resistance."

\section{Manuel Jiménez}

Since 1979, Tulare County Farm Advisor Manuel Jiménez has seen tremendous changes in his clientele of Filipino, Japanese and Hispanic growers. Many who farmed then have gone out of business, victims of a volatile vegetable market.

"Small farms are a way of life," Jiménez says, "but in terms of economics, it's cruel." He believes the challenge for Tulare County small farmers is to generate adequate net income to support a family. Although the standard of living has genercontinued on p. 12 


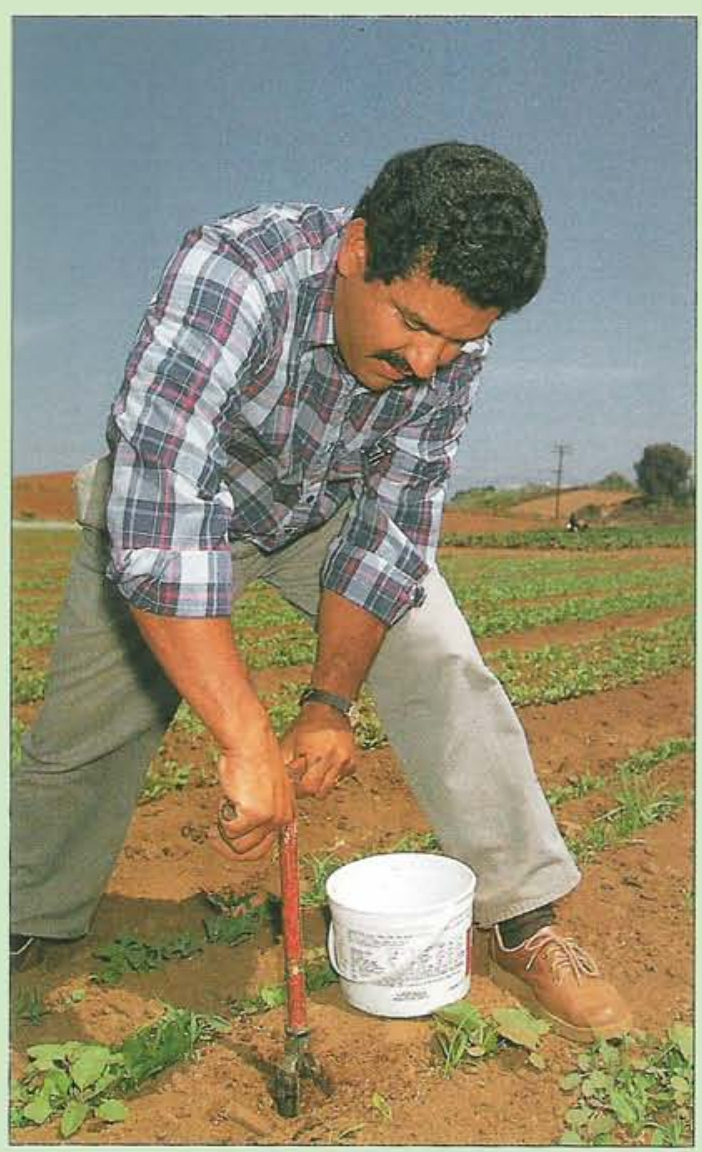

efforts earned him the 1991 American Farmland Trust agricultural conservation award for localized public education.

Muñoz is now developing a project to foster a socially, environmentally and economically sustainable niche for San Diego County's small farms. Working with Borevitz, other farmers and local community leaders, Muñoz wants to build a center where farmers can learn new techniques, consumers can buy locally grown produce, and schoolchildren can learn about where food comes from.

The guiding principle behind the project is a cooperative approach in which "members" invest time and/or money in exchange for farm-fresh food and smallscale farmers are guaranteed a reliable local market. It is called community-supported agriculture (CSA), and its proponents describe it as "a form of cooperation between farmers and consumers who come together to produce healthy food in a sustainable way."

Muñoz has applied for a grant from the Kellogg Foundation to begin the project. Once established, an advisory committee of small farmers, farm workers, consumers, community leaders, government agencies and Extension staff would steer such project activities as:

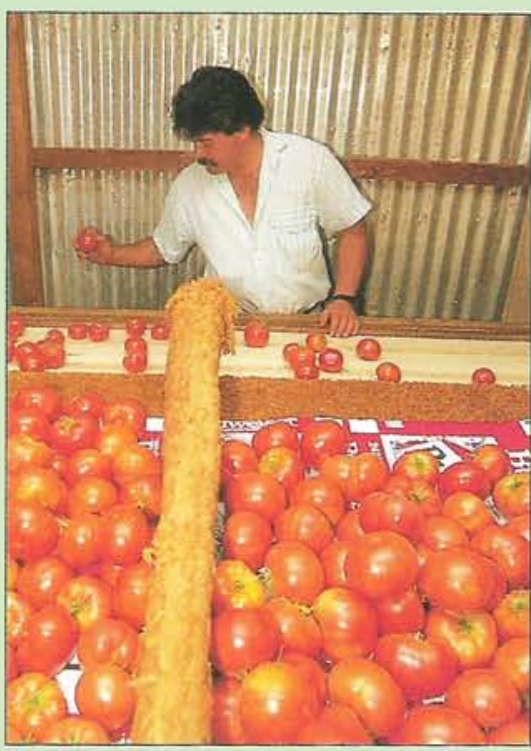

Above, Carlsbad farm worker sorts tomatoes in grower Francisco Valdivia's small, on-site packing house.

\section{Left, San Diego County Farm Advisor} Faustino Muñoz takes a soil sample from the JR Organics farm for a laboratory analysis. Recent seed germination problems may be linked to salt buildup from composted chicken manure; Muñoz has encouraged legume cultivation to diversify the farm's soil fertility program.

- A business plan and feasibility study for the regional produce market, farm demonstration site and agricultural science center.

-Educational programs for migrant farm workers and their families in nutrition, youth development, leadership training and pesticide safety.

- A farm worker organic garden with accompanying short courses and field demonstrations.

- Establishment of a direct marketing connection between an organic farm and an adjacent senior citizen community.

- Field demonstrations and seminars on sustainable and organic agricultural practices.

In the long term, Muñoz hopes, the project will result in a plan that protects the environment, provides high-quality local produce and supports the economic viability of small family farmers. The San Diego project reflects the progress made by proponents of sustainable agriculture.

"I like to think we've helped to take the myth out of it," Muñoz says. "Sustainable agriculture is no longer viewed as extremist. It's a more legitimate, acceptable and worthwhile goal. The program has also helped UC to define its role in sustainable agriculture in the state and nationally." - J. Stumbos

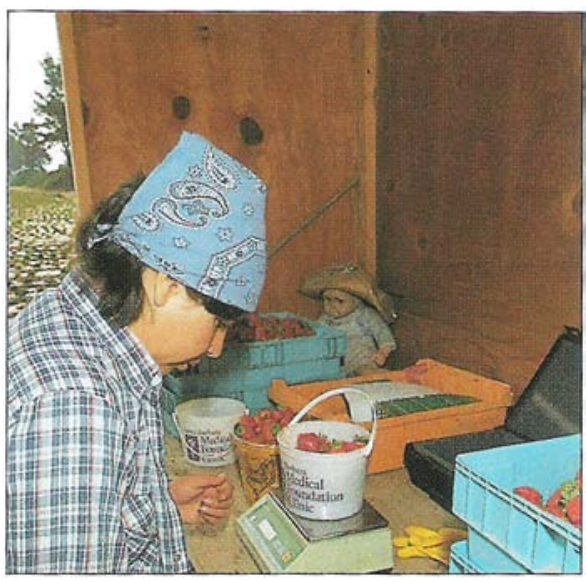

Harvesting technician Patricia Michel weighs fruit from a demonstration plot of UC-developed strawberries in the Santa Maria area.

\section{UC program (continued from p. 10)}

ally improved, small farm income has lagged, causing some families to seek offfarm employment and others to quit farming altogether.

Jiménez, whose area of expertise is specialty crops, conducts a broad-ranging research and education program on all aspects of crop production, management and marketing. He encourages some small-scale farmers, especially those growing grapes, tree fruit and nuts, to take advantage of the expertise offered by other advisors in the Tulare County office.

Jiménez has successfully developed control of the tomato pinworm (TPW), Kieferia lycopersicella, a major pest of cherry tomatoes that threatens to become an equally serious pest of other fresh market and processing tomatoes.

Damage occurs when TPW larvae burrow under the fruit's calyx, making it difficult to sort out infested fruit. Because growers cannot remove the calyx to detect damage, tolerance for the pest is virtually zero. Economic losses to small-scale farmers who produce most of the "cherries" has been devastating. Rather than risk unmarketable crops, many apply insecticides extensively - as much as 12 times in a season is not uncommon. In spite of this barrage, TPW damage is high, compounded by secondary outbreaks of another pest, the vegetable leafminer, Lyronmyza sativa.

With the help of a private company and other UC scientists, Jiménez began seeking an alternative to control the pest. Several years later, they developed a "pheromone confusion" technique that successfully disrupts the pest's reproductive cycle. The technique involves flooding a tomato field with the scent of female pinworms, frustrating the attempts of male pinworms to find mates.

\section{Louie Valenzuela}

More than a dozen years ago, when he graduated in agricultural economics, Louie 


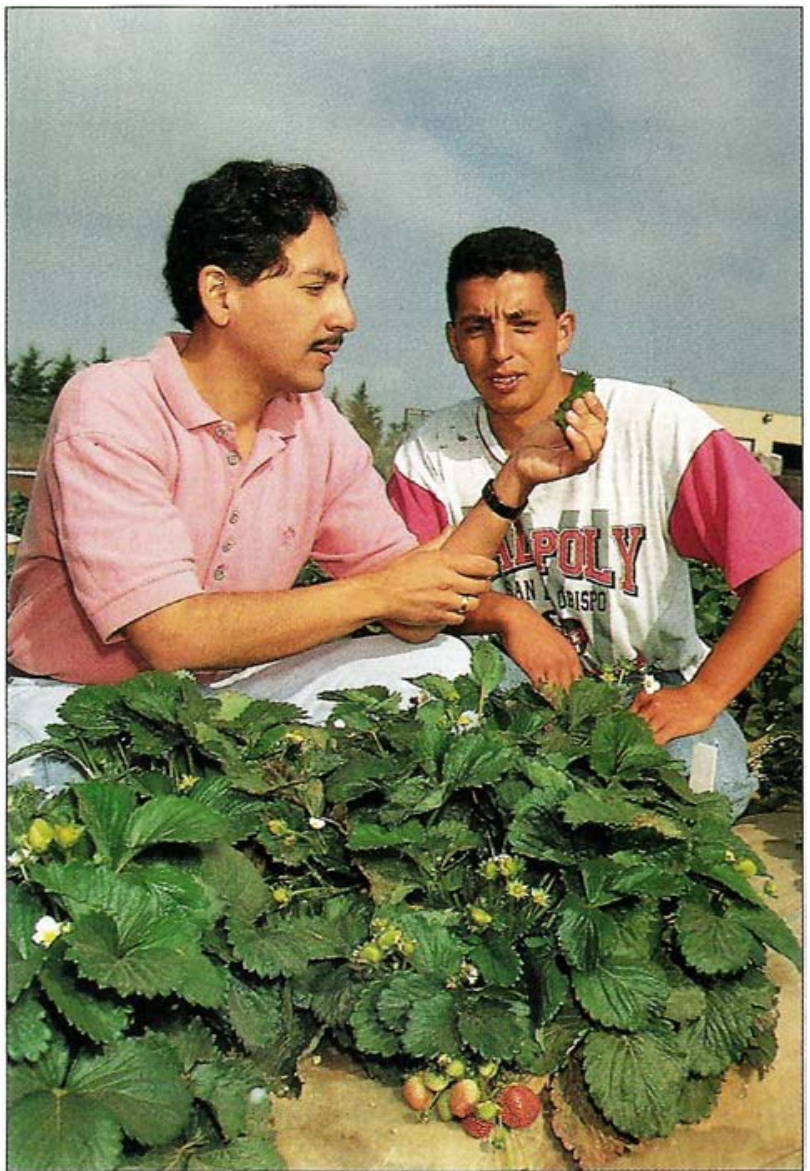

Funded by the California Strawberry Advisory Board, Farm Advisor Valenzuela (left) developed production guidelines for Santa Maria-area strawberries. Assisting him was Jose Guerra, agribusiness student at Caljfornia Polytechnic University.

Valenzuela expected to be keeping banker's hours by now. Instead, he works the hectic schedule of a UC farm advisor in Ventura, Santa Barbara and San Luis Obispo counties, where he helps dozens of small-scale, mostly Latino strawberry and specialty crop growers turn dreams into profits.

It all started with the farm worker cooperatives of the 1970s, Valenzuela explains, when public concern"over the plight of California farm workers led the U.S. Department of Agriculture to organize small-scale producer cooperatives in several areas of the state.

At about the same time (1979), Valenzuela graduated from UC Davis and landed a job with the Minority Business Development Agency to help small-scale growers with loans, financial management and marketing. Two years later, this would-be banker's background proved useful to the struggling cooperatives.

Most of Valenzuela's "clients" had some background in farming, but they lacked a grasp of production and marketing. They needed information on financing, bookkeeping, pest control, marketing, regulations and all the other headaches of managing a small business. They also

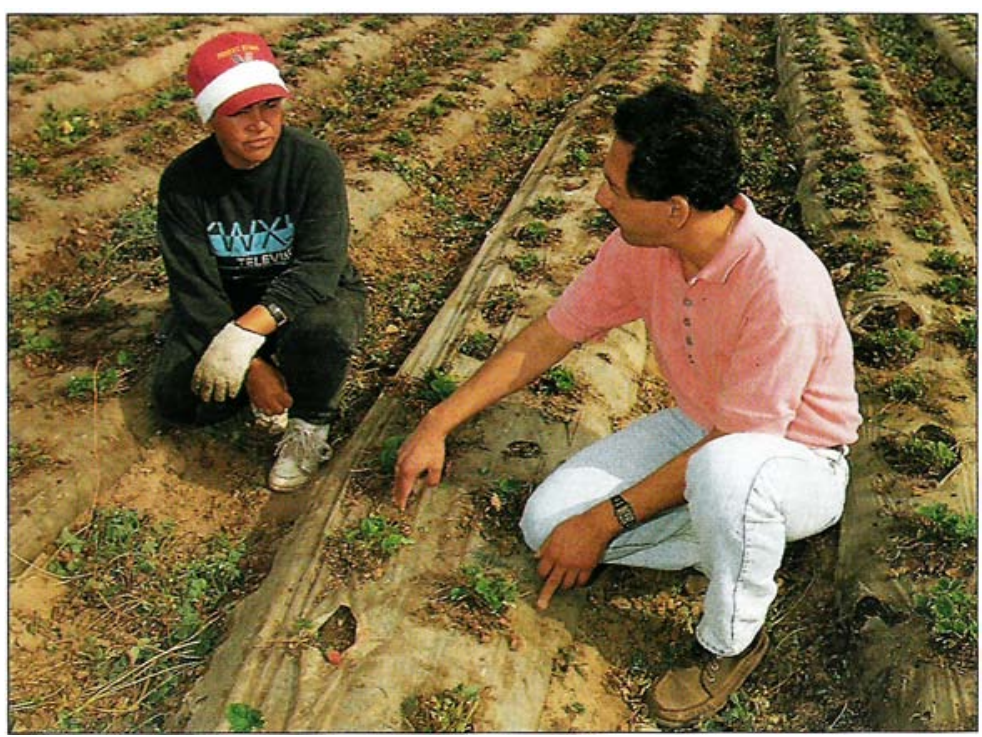

Valenzuela has helped strawberry growers such as Julia Magaña through on-site visits and local grower meetings.

needed to penetrate an invisible wall of cultural exclusion. "They were new within the community and needed support from the infrastructure," Valenzuela says.

When Valenzuela started to work with Cooperative Extension in 1981 , he set out to identify just the small farmers within his counties. For the first 2 or 3 years he drove around the countryside scouting would-be clients. Eventually, he developed a mailing list identifying commodities produced by individual farmers to facilitate a dialogue between them and the resource people needed to make their operations successful: pest control advisers, marketing agents, bankers and consultants.

For entry-level strawberry producers and production cooperatives, Valenzuela organized educational farm management programs, where the basics of keeping adequate financial records and producing financial statements were taught. He also helped small farmers locate financial assistance, including loan guarantees.

Luis Guevara, a former farm worker turned grower, has worked closely with Valenzuela, cooperating in field trials and demonstrations of drip irrigation and plastic mulches. "There are a lot of things to learn, not just growing," he says. "It's management and marketing. You need to know what the diseases are and what to do about them. The main thing is to have someone to tell me what I need to do."

The success of this farm advisor's work - whether with small farmers or other clientele - can be measured by the dramatic changes in Santa Maria. Now there are local pest control advisers, farm supply stores, bookkeepers and payroll services, and marketing firms that cater to Spanish- speaking farmers. Perhaps more symbolically, two small-scale producers from his region, including Guevara, have served on the statewide Strawberry Advisory Board. They persuaded the board to appropriate funds to study local growing conditions, a first for the board.

\section{Richard Smith}

Richard Smith, the newest of the designated small farm advisors, was previously stationed in Stanislaus County as a vegetable crops farm advisor. In 1989, Smith was reassigned to San Benito County. His territory also includes Monterey, Santa Cruz and Santa Clara counties. "The Central Coast," Smith says, "has a large concentration of small-scale growers and each of the four counties where I work has unique needs and clientele."

Among them are Hispanic strawberry and vegetable growers with limited English speaking skills and organic growers who need information on alternative production practices. One way to get this information out to growers is through a newsletter, Central Coast Family Farm Report. (Some articles of interest to Spanishspeaking audiences are written in both English and Spanish.) Newletter topics have included guidelines for using insecticidal soap, information on farmland trusts, diseases of cover crops and smut on sweet corn. Smith has also developed an Extension program in integrated pest management control of lygus bugs on strawberries and a research project to develop alternative fertilizer programs for organic growers.

Smith is particularly enthusiastic about his work with the Rural Development Center near Salinas, a program that leases small parcels of land to resource-poor, mostly Hispanic farm workers. Affiliated with the Association of Community Based continued on p. 15 


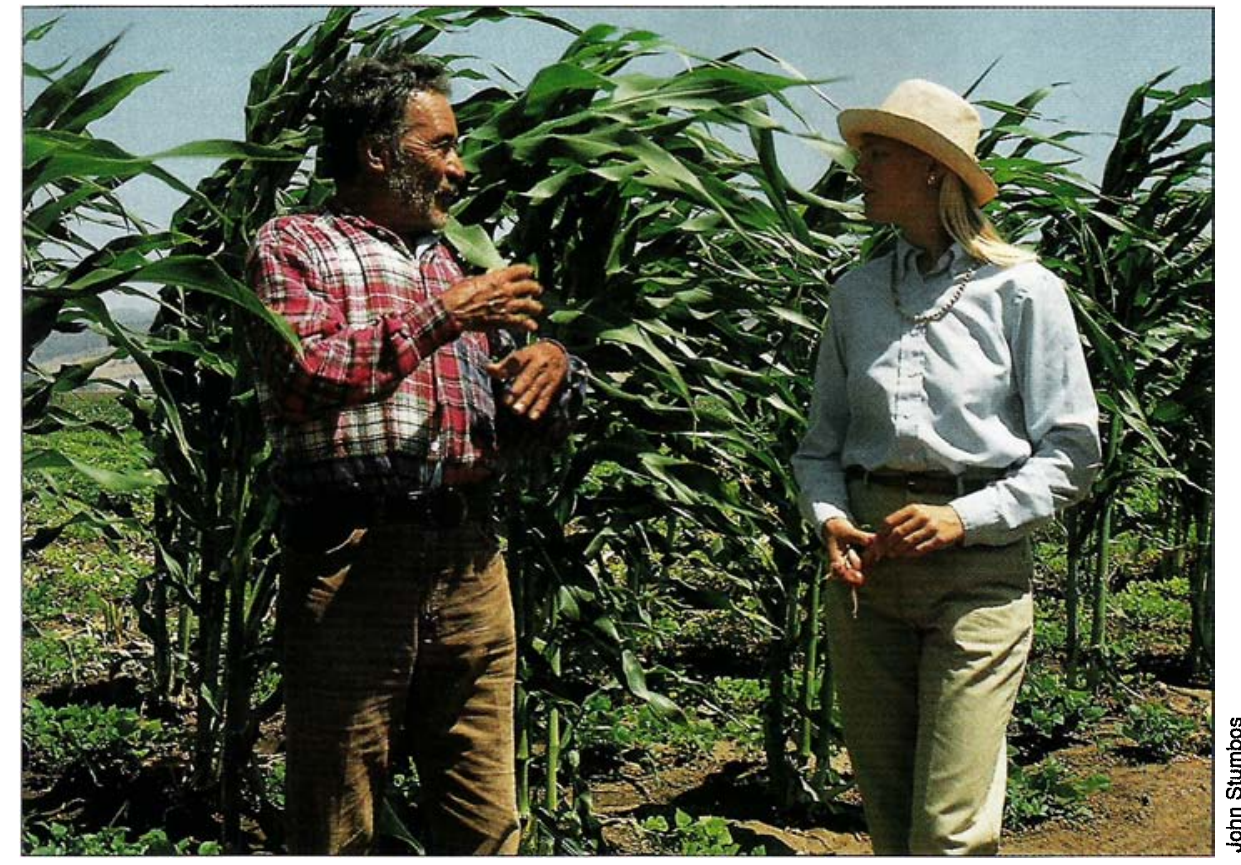

\section{UC program (continued from p. 13)}

Education, the center has a 3-year program that teaches the farm workers how to become better farmers and marketers.

Smith also conducts variety trials on brightly colored and uniquely shaped summer squash with names like Scaloppine and Sunburst. He says, "Restaurants just go nuts for that stuff because it has eye appeal. These small growers can't compete with the larger growers unless they grow something different. Jicama, that's a smart crop for these growers. It doesn't grow quite as large as it does in other areas, but it's fresher and it tastes better. Local jicama can be in markets in San Jose and Salinas in 1 day, not 2 weeks."

\section{University expertise}

One strength of the Small Farm Program has been its ability to coordinate university faculty, specialists and advisors. For example, to fight the Tulare County tomato pinworm, UC Riverside entomologist Nick Toscano and Tulare County entomologist Don Flaherty (now retired) helped Jiménez design the research and analyze the results of the pheromone confusion.

The Rural Development Center in Salinas is another example of university expertise coming to the aid of small farmers. Besides Smith and his work on marketable vegetable varieties there, Pedro llic has also stopped by to discuss his work on small-scale vegetable production with center students. Much of the center's direction originated with Miguel Altieri, associate professor, UC Berkeley Division of Biological Control, and Paul Gersper, associate professor, UC Berkeley Department of
Soil Science. They envisioned a place where farm workers would learn about low-input production methods that could be put into successful practice.

By virtue of their location or inclination, some UC farm advisors like to work with small farmers, regardless of whether they have been designated to do so. This is especially true in Northern California, where many Extension offices already work with a high percentage of small farms.

Glenn McGourty in Mendocino County, for instance, works with several hundred small farms that raise a variety of commodities, and emphasize nursery crops: Christmas trees, cut flowers, rhododendron, rare perennials, even Japanese maples. McGourty sees "a steady stream" of retirees, counterculture types and other entry-level farmers who simply want to live and work surrounded by the natural beauty of the North Coast.

The needs of these neophyte agriculturalists differ from those who farm the county's traditional mainstays: pears, grapes and timber. But, he says, diversification is broadening Mendocino County's economic base. A conference on specialty crops and alternative agriculture that McGourty organized several years ago, drew more than 100 people who wanted to make the transition from conventional to organic farming and to learn how to create value-added products and market organic produce.

The impact of Extension programs like McGourty's was reflected late last summer at "Mendocino Bounty," a tasting of locally produced and processed specialty

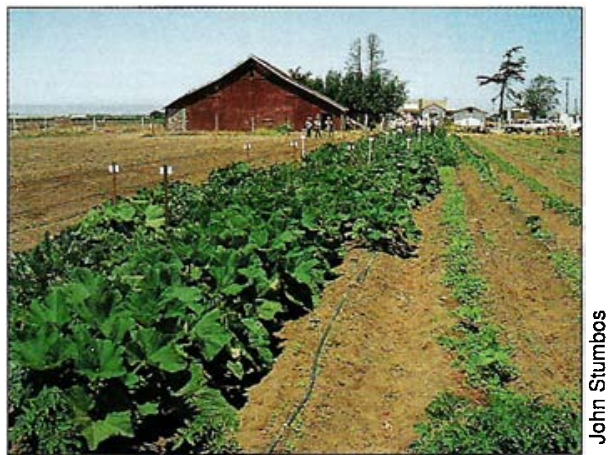

Above, a summer squash variety trial being conducted at the Rural Development Center by Farm Advisor Richard Smith.

At left, Ann Baier, education and development director for the Center, helps a farm worker who is learning the skills of smallscale production. foods: apples, pears, peppers, pickled kelp, rabbit, cheese, smoked salmon, baked goods, sausage, mustard, beer, wine and mineral water. Like other UC farm advisors, McGourty functions as a behindthe-scenes motivator, coordinator and consensus builder, and the highly successful event drew 80 vendors, 10 restaurants and more than 1,000 visitors to the county fairgrounds in Boonville.

Tastings, where local growers can show off specialty items to restaurants or the public, have become popular in last decade (see opposite page). Santa Clara County Farm Advisor Nancy Garrison, with an active group of Master Gardeners, has organized comparative taste tests of specialty fruits and vegetables grown at local farms and at the university's 17-acre Bay Area Research and Extension Center in San Jose. Her variety trial research on specialty lettuces, melons and tomatoes, as well as pepinos, cape gooseberries and white sapote, is geared toward finding high-quality, high-value commodities for local small-scale growers.

Urban encroachment has forced out many Santa Clara County farms, but some have survived to carve out successful niches for themselves. One such farm belongs to Andy Mariani, whose family has farmed in Morgan Hill for 35 years. Garrison says, "They've been able to survive because of their willingness to commit to high quality and to develop innovative marketing strategies. As Andy will tell you, they don't make money by simply producing apricots. They make money by continued on p. 17 
Far left, Sebastopol apple grower Darrel Hurst owns and operates one of the few remaining packing houses in Sonoma County. He and other hard times in the industry learned to market their products directly to the consumer. Hurst's farm is one stop on a "Farm Trails" map of the region.

Left, Carmen Kozlowski (center) with daughters Cindy (left) and Carol. Starting in 1951 with a 20acre orchard of Gravenstein apples, the family diversified their business. Today they market Kozlowski Farms jams and jellies to visitors and mail-order customers nationwide.

Right, Farm Advisor Vossen holds tray of raspberries from the Kozlowski farm. growers who survived

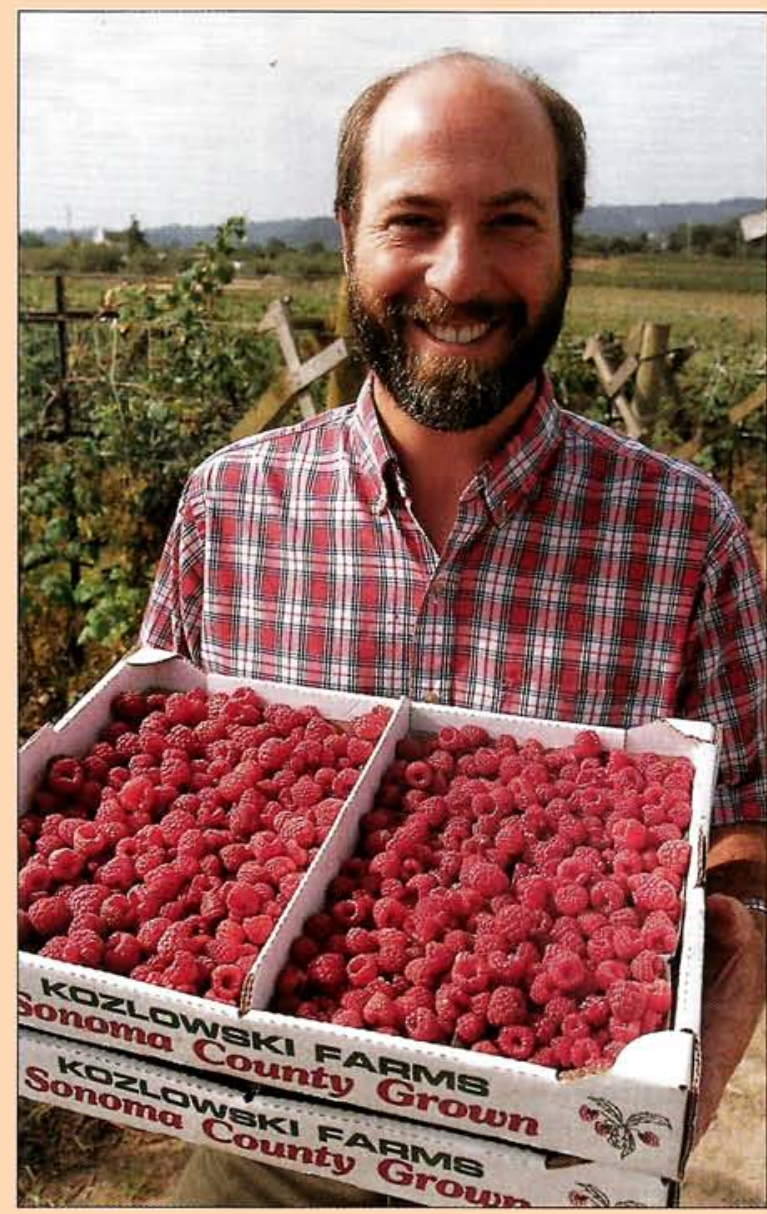

SCAMP membership has grown from 18 to 270-plus grower-processor and associate members, whose efforts have produced:

-The "Sonoma Select" logo to help consumers identify locally grown items.

- Seminars to help farmers evaluate their products, identify consumer demand, expand distribution, and learn communications skills.

-Booths at local fairs, farmers markets, in-store food tastings and other promotional events.

- Research into consumer attitudes about Sonoma County products.

- A marketing newsletter published for the agricultural community.

-Point-of-sale materials created for use in grocery stores.

- Employment of a merchandising salesperson to act as liaison between SCAMP members and markets.

- Promotional ads developed for radio, television, print media and billboards.

Historically, Sonoma County, especially Sebastopol, has always been known for its apples. Failure of the local cannery, competition from Washington state, escalating land values and urban encroachment have taken a toll on apple production. Once there were 25 packing houses near Sebastopol; now there are four.
Surviving growers formed the Sebastopol Apple Promotion Committee to boost sales and stabilize their industry, but they lacked a comprehensive marketing plan and were wasting money on ineffective promotions. Then a local supermarket advertisement for apples from "Apple Hill" in El Dorado County spurred them to action. "They got angry and said if they can do this, we can do it, too," Vossen says.

He helped growers focus on two objectives: getting local apples into local stores and getting them labeled as to Sonoma County origin. A newly hired marketing consultant and Vossen met with the five major supermarket chains in the area, and retail advertisements and point-of-purchase materials, such as recipe tear-offs, were established. The farm advisor also helped design a 7- by 11 -inch placard featuring two children admiring Sonoma County "farm-fresh" apples.

Vossen's emphasis on marketing is unusual; most farm advisors focus on production-related issues, but his involvement has reaped dividends for local apple growers and other small-scale Sonoma County growers. Produce buyers used to play one grower off another to get the lowest price, but for the last 5 years growers have seen fresh apple sales increase and prices stabilize. - J. Stumbos

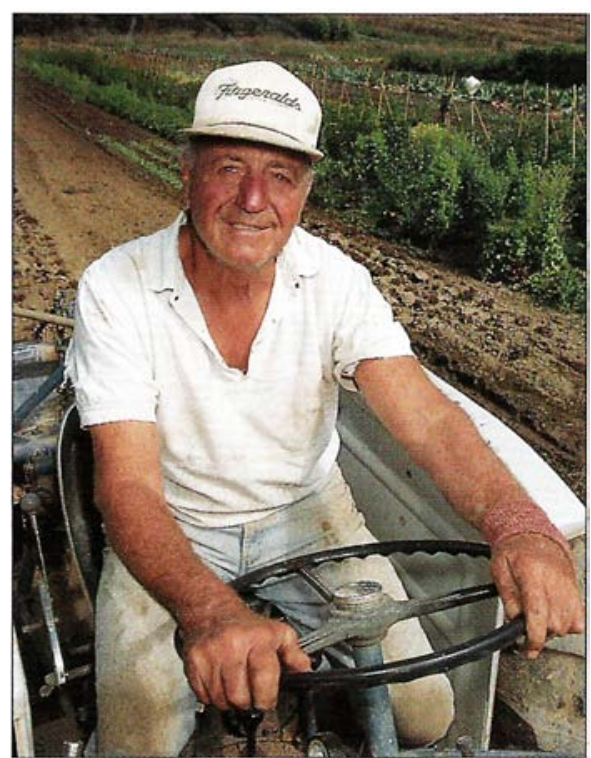

A relative newcomer to California, Antonio "Nino" LaScala cultivates Little Hill Farm in Sonoma County. "California is the place to grow vegetables," he says. "All you need is water!"

UC program (continued from p. 15) drying, processing and marketing them in an eye-catching way."

Cooperative Extension research and public service efforts benefit small farmers throughout the state. A glance at a recent Small Farm Program annual report describes:

- Stanislaus County Farm Advisor Jesus Valencia's "super sweet corn" variety field day.

- Contra Costa County Farm Advisor Janet Caprile's "creative cover crops" workshop.

- Extension Agricultural Engineer Jim Thompson's development of guidelines for low-cost, cold storage units.

- Yolo County Farm Advisor Gene Miyao's work on solarization for weed control.

-Extension Specialist Marita Cantwell's heat treatment to control postharvest pathogens of produce.

- Placer County Farm Advisor Garth Veercamp's Christmas tree irrigation study.

\section{The Small Farm Center}

While county-based advisors tailor research and Extension programs to meet local needs, the program's nucleus is the Small Farm Center at UC Davis. Established in 1980 with federal Rural Development Act funds, the center:

-Serves as a clearinghouse for questions from farmers, marketers, farm advisors, trade associations, government agencies and the academic community.

- Maintains a library of books, scientific and popular journals, reports, directories and periodicals covering production and marketing. 


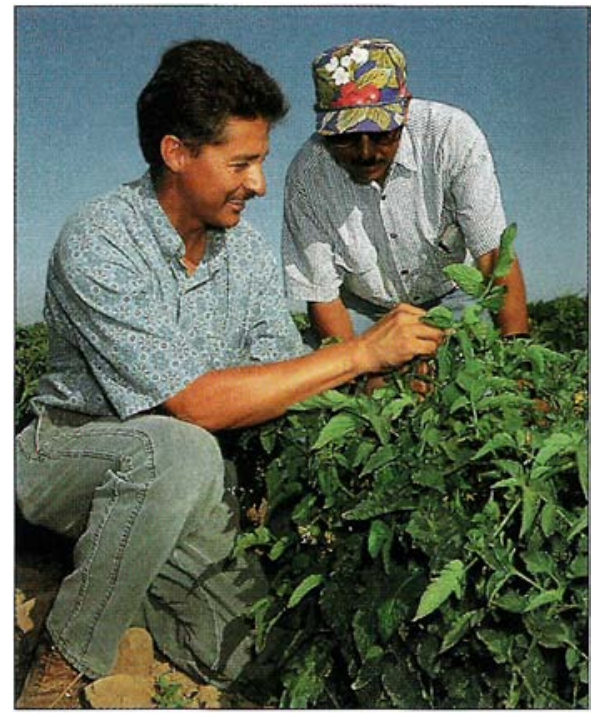

Francisco Resendiz (at right) and his family grow peaches, plums, nectarines, apples, apricots, persimmons and sweet corn on a farm near Modesto. Resendiz also works closely with Stanislaus County Farm Advisor Jesus Valencia (above) on variety trials.

-Publishes manuals, proceedings, booklets, leaflets and a bimonthly newsletter, Small Farm News, that reports on upcoming events, new publications, practical information on topical issues, and profiles of farmers and farm advisors.

- Organizes and coordinates statewide conferences, workshops, tastings and symposia, and supports advisors, farmers' markets and farm organizations in regional and local programs.

Says Program Director Voss, "Our mission is to help small farmers compete and survive by offering practical, positive solutions; and the experience of other producers and marketers is commonly the best source for these solutions."

Probably the most visible method of extending practical information is the Farm Conference, held each February in a different location in the state. The first conference in 1982 gave rise to the California Association of Family Farmers (CAFF). The Small Farm Center organizes the Farm Conference with groups like the Committee for Sustainable Agriculture, CAFF, the Marin County Farmers' Market, the Southland Farmers' Markets Association, and county Farm Bureaus. The conference features workshops on production and marketing, tours of successful small farms, nationally known speakers and tastings of food from local small farms.

The Small Farm Center's staff of Associate Director Claudia Myers, Program Representatives David Visher and Shirley Humphrey, and Administrative Assistant Linda Vierra are involved in an array of activities. These include:

-Publishing the Farmer-to-Consumer Directory, a statewide guide to roadside stands, U-pick farms, certified farmers' markets and other direct marketers.

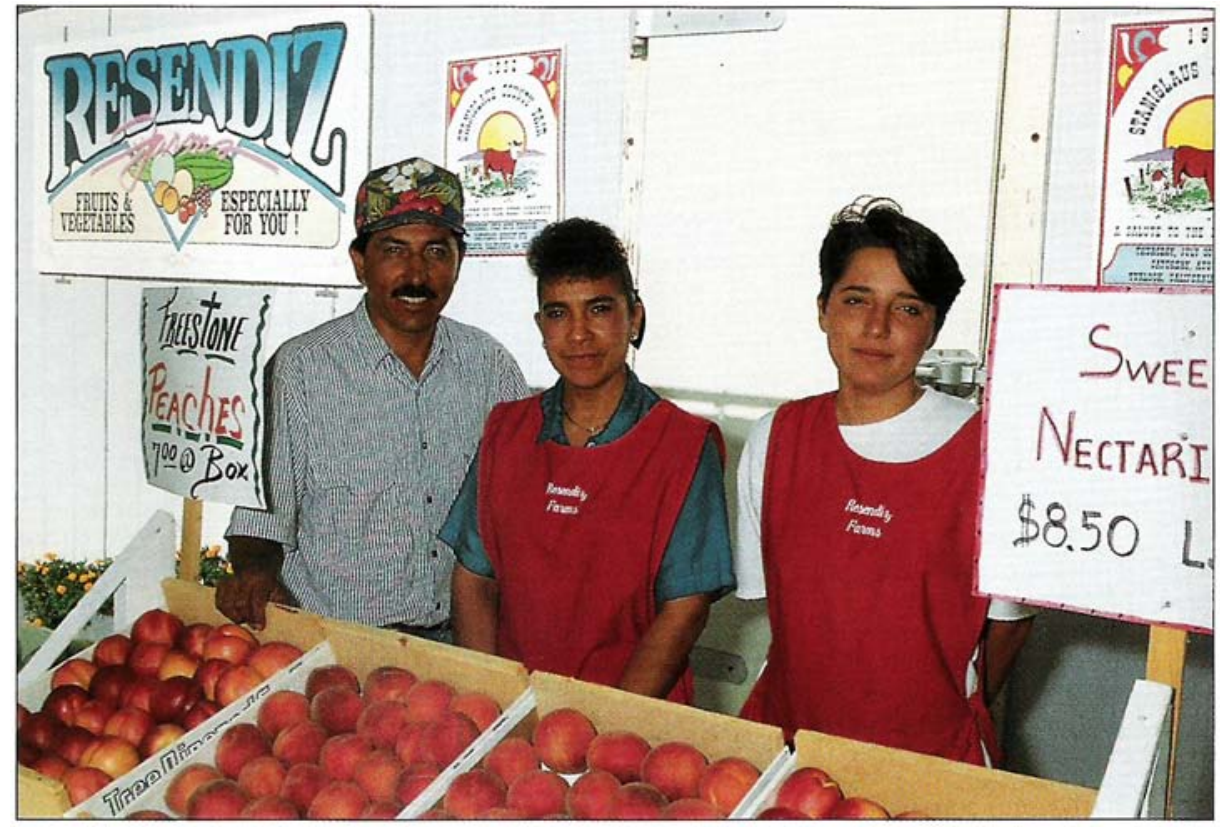

- Regional food tastings during September in Sacramento and Mendocino County.

-The Organic Farming Symposium in January 1992, an important step toward building dialogue between organic farmers and academia.

- A manual for entry-level farmers (now in press).

- A conference on Women in Agriculture in January 1992 (expected to convene again in fall, 1993).

-Spanish language publications on soil management and farming (published early this year).

- A Farmer-to-Consumer conference on the Central Coast (in November of 1991).

-Three regional field days on reducing fertilizer usage (in February and March this year).

- Additions to the Specialty and Minor Crops Handbook, a looseleaf publication published by the Division of Agriculture and Natural Resources (ANR Publication 3346).

The center is more than a service unit for farm advisors and specialists, and it is not a clearinghouse for grants. In many respects the center functions more like a county Cooperative Extension office, with much direct contact with the public.

\section{The future}

The needs of small-scale farmers are as compelling as they are varied. The university's challenge: How can it meet the growing needs of small farmers with its resources already stretched?

In a March 1992 report, the review team recommended that the Small Farm Program maintain a strong Small Farm Center, create a program advisory committee and establish a competitive grants program (but not at the expense of existing personnel or resources).
The degree to which small farmers thrive in California, the review team concluded, may well depend on the university's ability to support research and Extension programs targeted at them. Perhaps the value of the program is best expressed by one farmer, Linda J. Davis of Santa Clara County, who wrote the university:

"As a woman in agriculture, I currently manage a 12-acre fruit ranch which has been in my family for 122 years and which has now been operated by four generations of women. I left an academic career to assume this traditional family responsibility five years ago. Since that time I have depended heavily upon the Small Farms Program community for the information, assistance and networking essential to our very survival as a small agricultural operation in an increasingly urbanized area. . .

The small farmer in California is a minority population that is not being substantively served by any other group. Small farms are actually on the increase in California as a traditional lifestyle that serves community needs for open space, historic preservation and a direct market of agricultural products for the public. Because we are not large commercial agribusinesses we are often isolated from each other and from sources of vital information that will keep us viable. The Small Farm Program has provided us with a forum for interaction and a source of answers."

J. Stumbos is a public information representative, UC Davis.

The author gratefully acknowledges the assistance of Ron Voss and Claudia Myers, director and associate director of the UC Small Farm Program, UC Davis; and Craig Kolodge, Jesus Valencia, and Pedro Ilic, farm advisors in Santa Clara, Stanislaus and Fresno counties, respectively. 